\title{
Growth and Mineral Content of St. Augustinegrass Cultivars in Response to Salinity
}

\author{
C.H. Peacock ${ }^{1}$ \\ Department of Crop Science, North Carolina State University, Raleigh, NC 27695
}

\begin{abstract}
A.E. Dudeck ${ }^{2}$ and J.C. Wildmon ${ }^{3}$
Environmental Horticulture Department, Institute of Food and Agricultural Sciences, University of Florida. Gainesville, FL 32611
\end{abstract}

Additional index words. nutrition, salt tolerance, turfgrass

\begin{abstract}
This investigation documented growth and nutritional responses of St. Augustinegrass 'Floralawn', 'Floratam', 'Floratine', and 'Seville' in salinized (conductivity =1.1 to $41.5 \mathrm{dS} \cdot \mathrm{m}^{-1}$ ) solution cultures. Averaged over all cultivars' tissue, Cl concentrations increased linearly as salinity increased, while Na concentrations reached a threshold at $10 \mathrm{dS} \cdot \mathrm{m}^{-1} \mathrm{during}$ 3 months of growth. Tissue $\mathrm{K}$ concentration decreased nonlinearly with increased salinity to $10 \mathrm{dS} \cdot \mathrm{m}^{-1}$, with 'Floratine' being the least affected. All cultivars apparently substituted $\mathrm{Na}$ for $\mathrm{K}$ until an optimum level was reached. Leaf tissue concentration of $P$ decreased linearly, while $\mathrm{Ca}$ and $\mathrm{Mg}$ decreased nonlinearly with increased salinity. The salinity level that caused a $50 \%$ reduction in Ca concentration was $24 \%$ lower for 'Floratine' than for other cultivars. Tissue color differences were more strongly correlated with $\mathrm{Ca}$ and $\mathrm{Mg}$ levels in 'Floratine' than 'Seville'. Differences in cultivar response were noted for K, P, Ca, and Mg, with 'Seville' being the most salt-tolerant among those evaluated, based on overall nutritional and growth responses.
\end{abstract}

Saltwater intrusion into groundwater supplies continues to be an increasing problem in Florida (Parker, 1975). Majordifferences in salt tolerance have been found among turfgrass cultivars in bermudagrass [ Cynodon sp. (L.) Rich.] (Dudeck et al., 1983; Francois, 1988; Youngner and Lunt, 1967) and in Seashore paspalumgrass ( Paspalum vaginatum Swartz.) (Dudeck and Peacock, 1985). St. Augustinegrass is the most widely used lawngrass in Florida, but it requires supplemental irrigation for optimum growth. Salt tolerance of St. Augustinegrass is reported to be excellent (Beard, 1973), but no information on the tolerances of various cultivars is available. This investigation was conducted to compare the effects of increasing salinity on plant growth response and nutritional status of the St. Augustinegrass cultivars Floralawn, Floratam. Floratine, and Seville when grown in differentially salinized solution cultures.

\section{Materials and Methods}

This experiment was conducted outdoors under a rain shelter during Summer 1983 using a solution-culture technique described by Dudeck and Peacock (1985). 'Floralawn', 'Floratam', 'Floratine', and 'Seville' were propagated vegetatively from authentic planting stock. On 20 Apr. 1983, four sprigs (each 6 to $8 \mathrm{~cm}$ long) of each cultivar were planted vertically in tapered plastic pots containing washed gravel. Each pot, $12.7 \mathrm{~cm}$ top diameter $\times 9.8 \mathrm{~cm}$ deep ( $\approx 1$ liter), with a hole in the bottom, was suspended by a 1.25 cm-thick plywood lid so that $7 \mathrm{~cm}$ of the pot bottom was submersed in 10 liters of tap water in a plastic pan. Solutions were aerated constantly and changed weekly. Two weeks later, tap water was replaced with 6.6 liters of half-strength Hoagland's no. 2 solution,

Received for publication 6 Nov. 1992. Accepted for publication 23 Nov. 1992. The cost of publishing this paper was defrayed in part by the payment of page charges. Under postal regulations, this paper therefore must be hereby marked advertisement solely to indicate this fact.

Associate Professor of Crop Science. Turf.

${ }^{2}$ Professor of Turfgrass Science.

${ }^{3}$ Graduate Research Assistant. Present address: Lake City Community College, Lake City, Fla. which was formulated with deionized water to $\mathrm{pH}$ 6.3. The bottom of each pot extended $3.5 \mathrm{~cm}$ into the solution. Top growth $5 \mathrm{~cm}$ above the gravel was removed weekly.

All grasses were considered established by 24 June, visually rated for color and density, and blocked uniformly within five replications. All were of acceptable quality. A salt mixture was formulated to approximate the average individual salt composition of seawater (Svedrup et al., 1959); it contained (in $\mathrm{mg} \cdot \mathrm{kg}^{-1}$ of dry salts) $788 \mathrm{NaCl}, 94 \mathrm{MgSO}_{4}, 73 \mathrm{CaCl}_{2}, 7 \mathrm{KHCO}_{3}$, and $6 \mathrm{KCI}$. This salt mixture was added at $0,6.4,12.8,19.2,25.6$, or $32.0 \mathrm{~g} \cdot$ liter $^{-1}$ to the nutrient solution to give six average maximum electrical conductivity (EC at 25C) levels of 1.1, 10.3, 18.8, 26.9, 34.5, or $41.5 \mathrm{dS} \cdot \mathrm{m}^{-1}$, respectively. Electrical conductivities were recorded just before and after weekly solution changes. To minimize osmotic shock to the plants, all salt concentrations were increased in increments of $6.4 \mathrm{~g} \cdot$ liter $^{-1}$ at 2-day intervals over 10 days or until final treatment levels were reached.

Roots extraneous to the pot were removed monthly for 3 months. Top growth extending beyond the circumference of the pot was removed biweekly in avertical plane along with leaf tissue $25 \mathrm{~cm}$ above the gravel. Tissue was dried in preweighed aluminum envelopes at $60 \mathrm{C}$ for $48 \mathrm{~h}$ to determine dry weights. Rate of top growth was based on the total of 6 biweekly harvests. At the end of the experiment, root tissue within pots was separated from crown tissue, and both were dried as noted. Crown tissue was defined as stems and leaves below the 5-cm clipping height. Dry crown and root tissues were weighed, ashed at $450 \mathrm{C}$ for $12 \mathrm{~h}$, reweighed, and the difference was taken as total crown or root weight to eliminate errors caused by small gravel or sand clinging to the tissue.

Leaf tissue for the last four harvests was bulked and ground in a Wiley mill fitted with a 20-mesh screen. Subsamples of $300 \mathrm{mg}$ were then placed in 50-ml beakers and ashed at 450C. Beakers were then cooled, the ash dissolved in $0.3 \mathrm{M} \mathrm{HNO}_{3}$, filtered through no. 42 Whatman filter paper, and the filtrate brought to $30-\mathrm{ml}$ volume. Aliquots were then analyzed for $\mathrm{Ca}, \mathrm{K}, \mathrm{Mg}, \mathrm{Na}, \mathrm{Fe}, \mathrm{Cu}$,

Abbreviation. EC, electrical conductivity. 
Table 1. Significance levels for dry weights and top growth elemental content in St. Augustinegrass cultivars as affected by clectrical conductivity (EC) in solution medium.

\begin{tabular}{|c|c|c|c|c|c|c|c|c|c|c|c|c|c|c|}
\hline \multirow[b]{2}{*}{ Source } & \multirow[b]{2}{*}{$\mathrm{df}$} & \multicolumn{3}{|c|}{ Dry weight } & \multirow[b]{2}{*}{$\mathrm{Ca}$} & \multirow[b]{2}{*}{$\mathrm{Mg}$} & \multirow[b]{2}{*}{$P$} & \multirow[b]{2}{*}{ K } & \multirow[b]{2}{*}{$\mathrm{Na}$} & \multirow[b]{2}{*}{$\mathrm{Cl}$} & \multirow[b]{2}{*}{$\mathrm{Fc}$} & \multirow[b]{2}{*}{$\mathrm{Mn}$} & \multirow[b]{2}{*}{$\mathrm{Zn}$} & \multirow[b]{2}{*}{$\mathrm{Cu}$} \\
\hline & & Top & Crown & Root & & & & & & & & & & \\
\hline Block & 4 & $* * *$ & $* * *$ & NS & $*$ & NS & $* * *$ & $* * *$ & *** & $* * *$ & $* * *$ & $* * *$ & $* * *$ & $* * *$ \\
\hline $\mathrm{EC}$ & 5 & $* * *$ & $* * *$ & $* * *$ & $* * *$ & $* *$ & $* * *$ & $* * *$ & $* * *$ & $* * *$ & $* *$ & $* * *$ & $*$ & NS \\
\hline Error A & 20 & & & & & & & & & & & & & \\
\hline Cultivar (C) & 3 & $* * *$ & $* * *$ & $* * *$ & $* *$ & $* * *$ & $* * *$ & $* * *$ & $* * *$ & $* *$ & $* *$ & $* * *$ & $* * *$ & NS \\
\hline $\mathrm{C} \times \mathrm{EC}$ & 15 & $* * *$ & NS & $* * *$ & $* *$ & $*$ & $* *$ & $* * *$ & $\mathrm{NS}$ & NS & NS & $* *$ & NS & $\mathrm{NSS}$ \\
\hline Error B & 72 & & & & & & & & & & & & & \\
\hline
\end{tabular}

vs. * **** Nonsignificant or significant at $P \leq 0.05,0.01$, or 0.001 , respectively.

Zn, and Mn using a Perkin-Elmer Model 460 atomic emission spectrophotometer. Aliquots were analyzed for $\mathrm{Cl}$ colorimetrically (Mitchell and Rhue, 1979). Turf color scores were recorded on a 1 to 9 scale, where 9 = best.

The design was a split plot with five replications in which salinity was the main plot effect and cultivar was the subplot effect. All data were subjected to analysis of variance or regression analysis. Inverse regression analyses within replicates of each cultivar were used to predict the yield decrements. With the nonlinear regression models, the best fit is expressed with the percent variability of the experimental model. Means between cultivars were then separated based on the Waller-Duncan K-ratio $t$ test, with K-ratio $=100$.
Results and Discussion

Interactions of cultivar $\mathrm{x}$ solution $\mathrm{EC}$ were observed for top and root growth, but not for crown growth (Table 1). Based on growth responses, 'Seville' was the most salt-tolerant cultivar, especially at low salt concentrations.

No interactions of cultivar $\mathrm{x}$ EC were found for leaf elemental content of $\mathrm{Na}, \mathrm{Cl}, \mathrm{Fe}, \mathrm{Zn}$, or $\mathrm{Cu}$ (Table I ). Tissue $\mathrm{Cu}$ concentrations were not different among cultivars and were not affected by salinity. The Fe, Mn, and $\mathrm{Zn}$ levels were affected by salinity levels, but the data did not fit linear regression analyses. Correlation of tissue Fe with EC was significant only for 'Floratine' ( $r=-0.37$, $P=0.05)$ and 'Seville' $(r=0.46, P=0.05)$ (Table 2). Tissue $\mathrm{Mn}$ content was correlated with EC levels for 'Floratine' ( $r=-0.41, P$ $=0.05)$. All other correlations of microelements with tissue con-

Table 2. Correlation of leaf elemental content and dry weight of roots and tops of four cultivars of St. Augustinegrass and electrical conductivity of the solution medium.

\begin{tabular}{|c|c|c|c|c|c|c|c|c|c|c|}
\hline $\begin{array}{l}\text { Cultivar } \\
\text { and criterion }\end{array}$ & K & $\mathrm{Ca}$ & $\mathrm{Mg}$ & $\mathrm{Cl}$ & $\mathrm{Na}$ & $\mathrm{Cu}$ & $\mathrm{Fe}$ & Mn & $\mathrm{Zn}$ & $\mathrm{EC}$ \\
\hline \multicolumn{11}{|l|}{ Floralawn } \\
\hline \multirow[t]{2}{*}{ EC } & -0.75 & -0.62 & -0.26 & 0.93 & 0.76 & 0.12 & -0.30 & 0.14 & 0.28 & --- \\
\hline & $* * *$ & $* * *$ & NS & $* * *$ & $* * *$ & NS & NS & $\mathrm{NSS}$ & NS & \\
\hline \multirow[t]{2}{*}{ Top } & 0.71 & 0.64 & 0.36 & -0.89 & -0.73 & 0.50 & -0.04 & 0.20 & -0.31 & -0.96 \\
\hline & $* * *$ & $* * *$ & $*$ & $* * *$ & $* * *$ & NS & NS & vS & NS & $* * *$ \\
\hline \multirow[t]{2}{*}{ Root } & 0.73 & 0.63 & 0.35 & -0.89 & -0.75 & 0.62 & -0.83 & -0.15 & 0.40 & -0.95 \\
\hline & $* * *$ & $* * *$ & $*$ & $* * *$ & $* * *$ & NS & NS & NS & NS & $* * *$ \\
\hline \multicolumn{11}{|l|}{ Floratam } \\
\hline \multirow[t]{2}{*}{ EC } & -0.72 & -0.63 & -0.32 & 0.96 & 0.78 & 0.14 & -0.01 & 0.07 & 0.25 & --- \\
\hline & $* * *$ & $* * *$ & NS & $* * *$ & $* * *$ & NS & NS & vis & NS & \\
\hline \multirow[t]{2}{*}{ Top } & 0.73 & 0.65 & 0.41 & -0.94 & -0.79 & 0.18 & 0.56 & -0.24 & -10.64 & -0.96 \\
\hline & $* * *$ & $* * *$ & $*$ & $* * *$ & $* * *$ & NS & NS & NS & NS & $* * *$ \\
\hline \multirow[t]{2}{*}{ Root } & 0.76 & 0.68 & 0.38 & -0.89 & -0.79 & -0.02 & 0.44 & 0.71 & -0.16 & -0.89 \\
\hline & $* * *$ & $* * *$ & * & $* * *$ & $* * *$ & NS & NS & NS & NS & $* * *$ \\
\hline \multicolumn{11}{|l|}{ Floratine } \\
\hline \multirow[t]{2}{*}{ EC } & -0.79 & -0.61 & -0.52 & 0.92 & 0.81 & 0.09 & -0.37 & -0.41 & 0.05 & --- \\
\hline & $* * *$ & $* * *$ & $* *$ & $* * *$ & $* * *$ & NS & $*$ & $*$ & NS & \\
\hline \multirow[t]{2}{*}{ Top } & 0.71 & 0.54 & 0.45 & -0.88 & -0.75 & 0.43 & -0.16 & -0.57 & -0.17 & -0.97 \\
\hline & $* * *$ & $* *$ & $* *$ & $* * *$ & $* * *$ & NS & NS & NS & NS & $* * *$ \\
\hline \multirow[t]{2}{*}{ Root } & 0.72 & 0.59 & 0.38 & -0.80 & -0.71 & 0.40 & 0.08 & 0.24 & 0.41 & -0.85 \\
\hline & $* * *$ & $* * *$ & $*$ & $* * *$ & $* * *$ & NS & NS & NS & NS & $* * *$ \\
\hline \multicolumn{11}{|l|}{ Seville } \\
\hline \multirow[t]{2}{*}{ EC } & -0.63 & -0.60 & -0.34 & 0.91 & 0.72 & 0.11 & -0.46 & -0.02 & 0.05 & --- \\
\hline & & $* * *$ & $* * *$ & $N S$ & $* * *$ & $* * *$ & NS & $* *$ & NS & NS \\
\hline \multirow[t]{2}{*}{ Top } & 0.46 & 0.45 & 0.18 & -0.79 & -0.56 & 0.72 & -0.17 & -0.25 & 0.39 & -0.94 \\
\hline & $* *$ & $* *$ & NS & $* * *$ & $* * *$ & NS & NS & NS & NS & $* * *$ \\
\hline \multirow[t]{2}{*}{ Root } & 0.35 & 0.37 & 0.04 & -0.60 & 0.40 & 0.46 & -0.16 & -0.54 & 0.13 & -0.69 \\
\hline & $*$ & $*$ & NS & $* * *$ & $*$ & NS & NS & NS & NS & $* * *$ \\
\hline
\end{tabular}

"s., ${ }^{* *},{ }^{* * *}$ Nonsignificant or significant at $P \leq 0.05,(0.01$, or 0.001, respectively. 


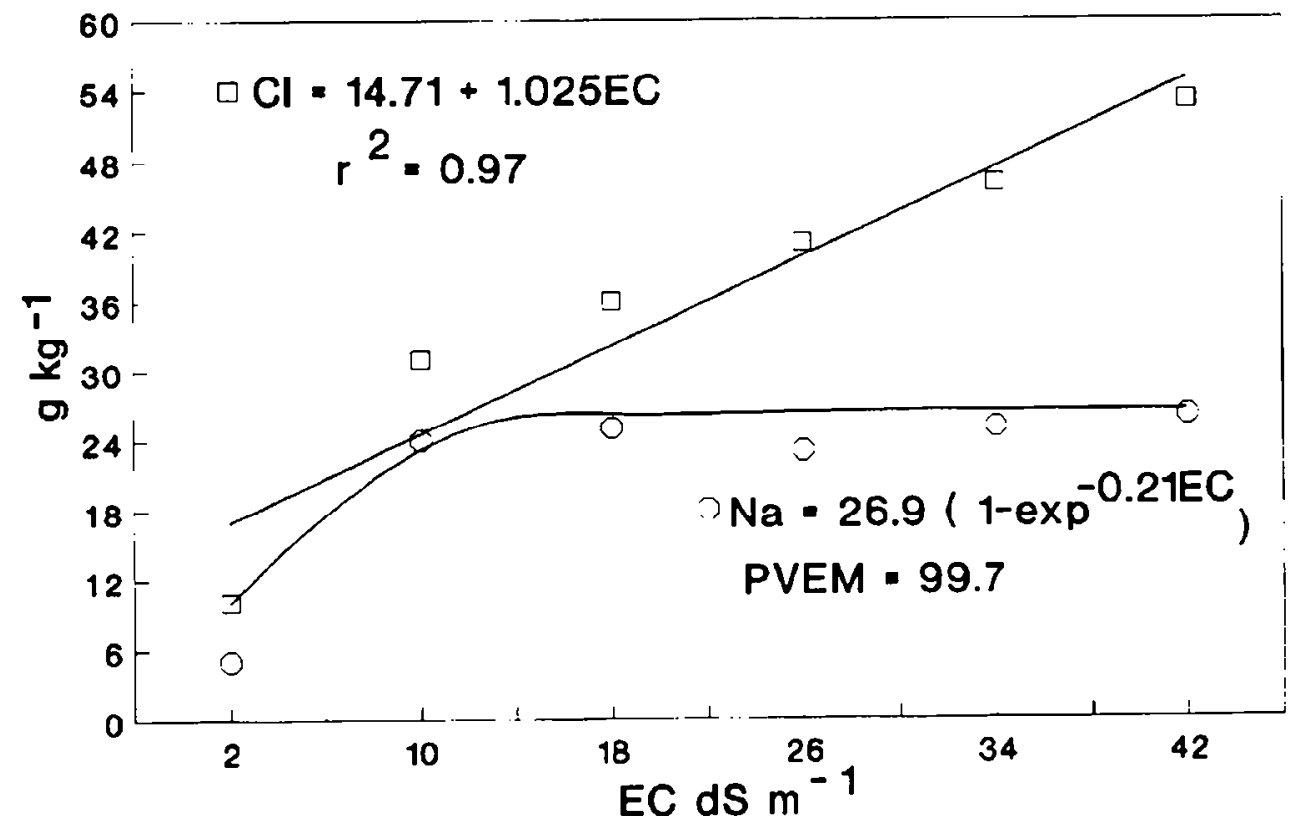

Fig. 1. Composite $\mathrm{Cl}$ and $\mathrm{Na}$ tissue response of St. Augustinegrass cultivars to salinity.

centrations and with top growth and root growth were nonsignificant within cultivars (Table 2).

Since there was no cultivar $\times$ EC interaction for $\mathrm{Na}$ and $\mathrm{Cl}$, data for regression analyses were averaged over all cultivars. As solution EC increased, tissue $\mathrm{Cl}$ increased linearly from $15 \mathrm{~g} \cdot \mathrm{kg}^{-1}$ at 1.1 $\mathrm{d} \mathrm{S} \cdot \mathrm{m}^{-1}$ to $53 \mathrm{~g} \cdot \mathrm{kg}^{-1}$ at $41.5 \mathrm{dS} \cdot \mathrm{m}^{-1}$ (Fig. 1). Increased tissue $\mathrm{Cl}$ concentrations with no apparent maximum have been noted in other grass species, including bermudagrass (Dudeck et al. 1983), bentgrass (Agrostis stolonifera L.) (Ahmad et al., 1981), alkaligrass [ Puccinellia distans (L.) Parl.] (Lunt et al., 1961), Seashore paspalum (Dudeck and Peacock, 1985), Highland bentgrass (A. tenuis Sibth.), Italian ryegrass (Lolium multiflorum Lam.), timothy (Phleum pratense L.), perennial ryegrass (L. perenne L.), tall fescue (Festuca arundinucea Schreb.), Kentucky bluegrass (Poa pratensis L.), and creeping red fescue (F. rubra L.) (Cordukes and Parups, 1971). Restriction of $\mathrm{Na}$ transport, but not $\mathrm{Cl}$, does occur in other plants: however, it usually is associated with species labeled as salt-sensitive rather than salt-tolerant (Marschner, 1986). Accumulation of $\mathrm{Na}$ reached a maximum at $\approx 10 \mathrm{dS} \cdot \mathrm{m}^{-1}$ and then remained unchanged (Fig. 1).

St. Augustinegrass maintained top growth with increased tissue $\mathrm{Cl}$ levels, indicating that it may inherently use compartmentalization to prevent toxicity of $\mathrm{Cl}$. Tissue $\mathrm{P}$ levels decreased linearly with increasing salinity, and there was a cultivar $\mathrm{x}$ EC interaction (Fig. 2). While some species have demonstrated an ability to absorb $\mathrm{Cl}$ without reductions of other anions (Bernstein and Hayward, 1958), tall wheatgrass (Agropyron elongatum L.) had reduced $\mathrm{P}$ with increased $\mathrm{Cl}$ in leaves (Shannon, 1978). In a comparison among bermudagrass cultivars, Francois (1988) found that tissue $\mathrm{P}$ levels were reduced under increased soil salinity; this apparently also occurs in St. Augustinegrass. Comparing P responses, 'Floratine' was the most sensitive cultivar based on the slope $(b=-0.061)$ of the regression line (Fig. 2). Salt-stressed plants exhibit symptoms similar to P-deficiency, including smaller, darker-green leaves, a decreased shoot : root ratio, decreased tillering, and prolonged dormancy of lateral buds (Hewitt, 1963). Symptoms similar to these have been observed under salinity stress in alkaligrass, although it was not attributed to P-deficiency, since tissue nutrient levels were not determined (Harivandi et al.,
1982). St. Augustinegrass growth reductions observed in this study could, in part, be attributed to lower salinity-induced tissue $P$ concentrations.

Tissue $\mathrm{Na}$ concentration increased nonlinearly, with an $89 \%$ increase at $10.3 \mathrm{dS} \cdot \mathrm{m}^{-1}$; however, tissue $\mathrm{K}$ concentration was the reverse of that for $\mathrm{Na}$, with concentration in all cultivars decreasing nonlinearly with increased salinity. The largest $\mathrm{K}$ decreases occurred at relatively low salt solution concentrations in comparison to dry weights. A comparison of conductivities at the $50 \%$ reduction point of $\mathrm{K}$ levels in the tissue (Table 3) reveals 'Floratine' to be the most efficient absorber of $\mathrm{K}$; the salinity level necessary to effect a $50 \%$ reduction in leaf tissue concentrations was $27 \%$ higher than for other cultivars. This decline in tissue $\mathrm{K}$ levels with increased salinity has been noted in other grass species, including bermudagrass (Dudeck et al., 1983), bentgrass (Ahmad et al., 1981), and Seashore paspalumgrass (Dudeck and Peacock, 1985). The decrease in tissue $\mathrm{K}$ concentration and increase in $\mathrm{Na}$ both exhibited a nonlinear response, with a maximum at $\approx 10 \mathrm{ds} \cdot \mathrm{m}^{-1}$. This pattern may represent a substitution of $\mathrm{Na}$ for $\mathrm{K}$ within the plant until a threshold level is reached. Sodium can substitute for $\mathrm{K}$ in substantial quantities with no growth reduction (Cope et al., 1953). although there can be an interaction with other cations.

Plant response to $\mathrm{Na}$ varies greatly depending on the species, the ratio of $\mathrm{Na}$ to other cations, and the total concentration (Devitt et al., 1984; Elgabaly, 1955; and Rathert, 1982). Accumulation of $\mathrm{Na}$ in Puccinellia distans also appears to reach a maximum concentration at $80 \mathrm{meq} / 100 \mathrm{~g}$ tissue content (Lunt et al., 1961), while tissue $\mathrm{Na}$ concentrations in Agrostis stolonifera continued to increase up to $300 \mathrm{~mm} \mathrm{NaCl}$ in the rhizosphere (Ahmad et al., 1981). Francois (1988) found that tissue $\mathrm{Na}$ increased as soil salinity increased with three bermudagrass cultivars. Wu (1981) noted that a lack of salt tolerance in certain genotypes of $A$. stolonifera and $A$. tenuis may be due to an inability of those varieties to exclude Na. Data from our research support a maximum for absorption and substitution of $\mathrm{Na}$ for $\mathrm{K}$ ions, which also could compete effectively with other cations and affect overall plant nutritional balance. Despite $\mathrm{K}$ fertilization not normally being strongly linked to increased top growth responses in turfgrasses, there was a strong correlation of tissue $\mathrm{K}$ levels to both 

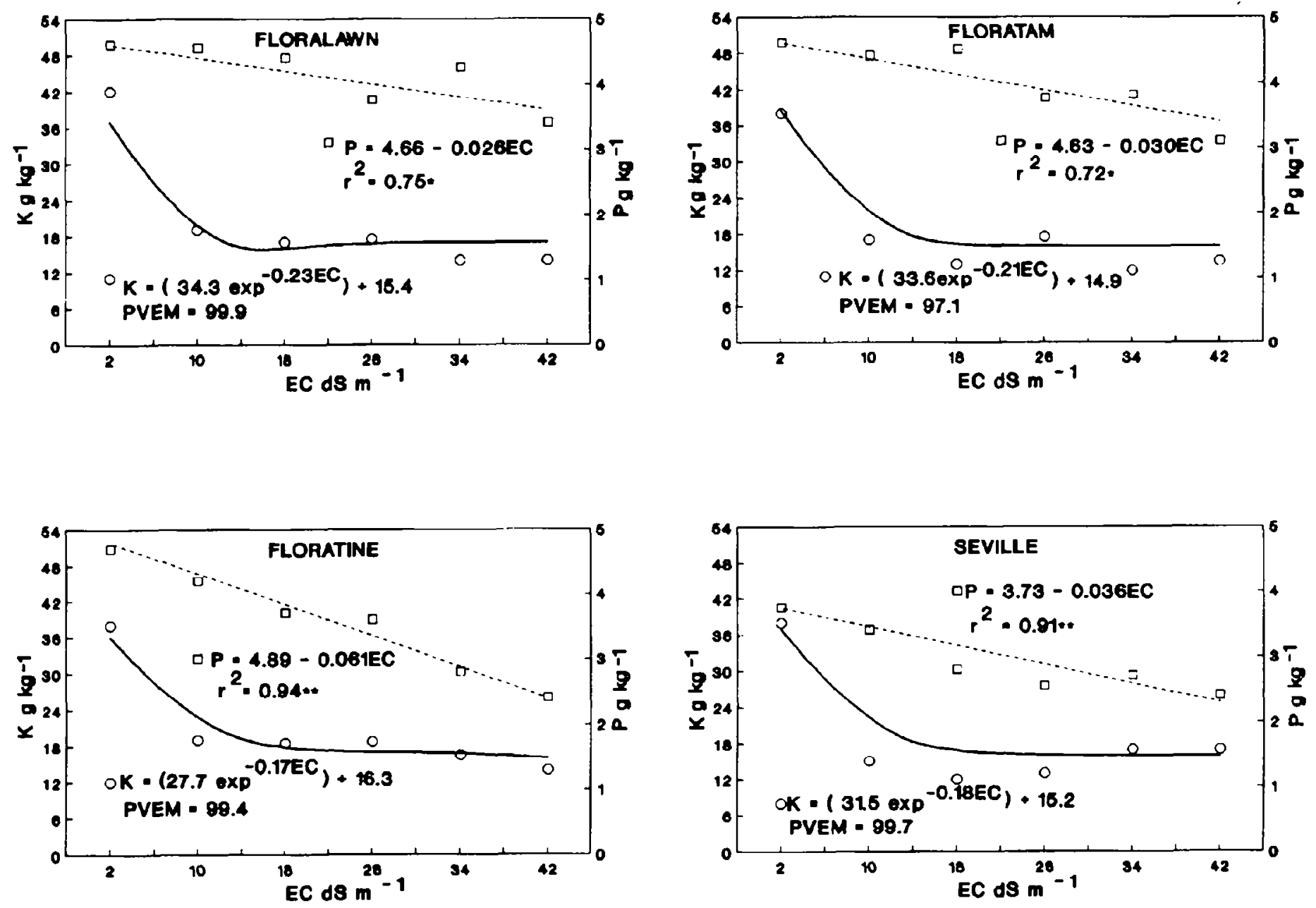

Fig. 2. Influence of salinity on P and K concentration in topgrowth of St. Augustincgrass cultivars.

top growth and root growth for all cultivars (Table 2).

Cultivars varied in their ability to absorb $\mathrm{Ca}$ and $\mathrm{Mg}$ under salt stress. Leaf tissue content of $\mathrm{Ca}$ and $\mathrm{Mg}$ decreased nonlinearly with increased salinity (Fig. 2). All cultivars initially had higher $\mathrm{Ca}$ contents than $\mathrm{Mg}$ in their tissue. At the first salt increment, tissue $\mathrm{Ca}$ levels fell rapidly below the $\mathrm{Mg}$ concentration. 'Floratine' was the least efficient absorber based on reduction of both $\mathrm{Ca}$ and $\mathrm{Mg}$ tissue concentrations under increased salinity (Table 3; Fig. 3). Tissue Ca concentration response of 'Floratine' to increased salinity was the opposite of $\mathrm{K}$. The EC level that effected a 50\% reduction in tissue $\mathrm{Ca}$ content was $24 \%$ lower for 'Floratine' than for other cultivars (Table 3). This nutritional difference apparently has no direct connection to yield, since top growth was more closely correlated to $\mathrm{K}$ than $\mathrm{Ca}$ or $\mathrm{Mg}$ (Table 2). Calcium is linked

Table 3. Predicted electrical conductivity of the solution medium to effect a $50 \%$ reduction in leaf tissue levels of $\mathrm{Ca}$ and $\mathrm{K}$ for $\mathrm{St}$. Augustinegrass cultivars

\begin{tabular}{lcc}
\hline \hline Cultivar & $\mathrm{Ca}$ & $\mathrm{K}$ \\
\hline & $d s \cdot m^{\prime}$ & \\
Floratam & $17.5 \mathrm{a}^{2}$ & $14.3 \mathrm{~b}$ \\
Floralawn & $17.4 \mathrm{a}$ & $14.8 \mathrm{~b}$ \\
Seville & $17.1 \mathrm{a}$ & $14.2 \mathrm{~b}$ \\
Floratine & $13.4 \mathrm{~b}$ & $19.4 \mathrm{a}$
\end{tabular}

"Mean within columns by the Waller-Duncan K-ratio $t$ test, $P \leq 0.05$. to membrane permeability and osmotic adjustment, and growth can be affected when $\mathrm{Na}$ : Ca ratios exceed 17: 1 (Greenway and Munns, 1980). In this study, even with 'Floratine', which had the lowest leaf tissue $\mathrm{Ca}$ concentration, the $\mathrm{Na}$ : $\mathrm{Ca}$ ratio did not exceed 14: 1 and, therefore, $\mathrm{Ca}$ levels may have been adequate to maintain nutritional balance.

Intensity of greenness is used as an indicator of plant vigor. Color scores of St. Augustinegrass were taken at 7 and 8 weeks and averaged over all salinity levels (Table 4). 'Seville' had the highest color scores and 'Floratine' the lowest. 'Floralawn' and 'Floratam' were intermediate, although similar to 'Seville' at 7 weeks. There was a stronger correlation of color to tissue $\mathrm{Ca}(r=0.712, P=$ $0.001)$ and $\mathrm{Mg}(r=0.629, P=0.001)$ levels in 'Floratine' than in 'Seville' (Table 5). Data for $\mathrm{Mg}$ were too variable to permit inverse

Table 4. Color scores of four St. Augustinegrass cultivars averaged over salinity levels after 7 and 8 weeks of salinization.

\begin{tabular}{llrl}
\hline & \multicolumn{2}{c}{ Time of rating (week) } \\
\cline { 2 - 3 } Cultivar & 7 & 8 & Mean \\
\hline Seville & $6.8 \mathrm{a}^{\mathrm{a}}$ & $6.6 \mathrm{a}$ & $6.7 \mathrm{a}$ \\
Floralawn & $6.5 \mathrm{a}$ & $5.9 \mathrm{~b}$ & $6.2 \mathrm{~b}$ \\
Floratam & $6.4 \mathrm{a}$ & $5.8 \mathrm{~b}$ & $6.1 \mathrm{~b}$ \\
Floratine & $5.5 \mathrm{~b}$ & $5.0 \mathrm{c}$ & $5.2 \mathrm{c}$
\end{tabular}

Mean separation within columns by the Waller-Duncan K-ratio $t$ test, $P$ $\leq 0.05$. 

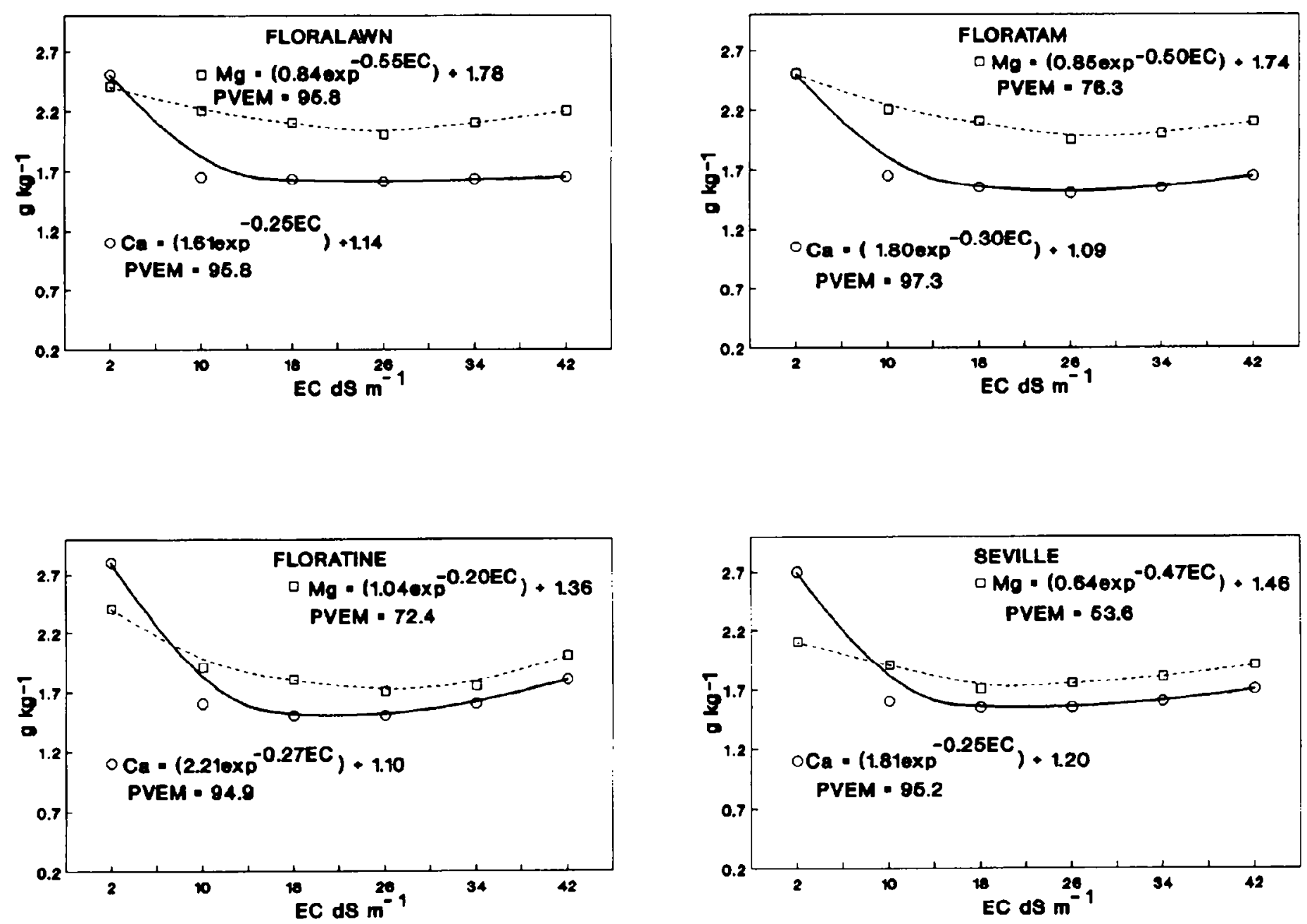

Fig. 3. Influence of salinity on $\mathrm{Mg}$ and Ca concentration in topgrowth of St. Augustinegrass cultivars.

regression analysis, but tissue content of $\mathrm{Mg}$ decreased $27 \%, 16 \%$, $14 \%$, and $13 \%$ at $10.3 \mathrm{dS} \cdot \mathrm{m}^{-1}$ in 'Floratine', 'Floratam', 'Floralawn' and 'Seville', respectively, compared to the lowest salinity treatment. Relationship of color to $\mathrm{Mg}$ content is well-known based on chlorophyll production. However, correlation of $\mathrm{Ca}$ to color is not as clear. In Kentucky bluegrass, color differences have been noted among cultivars in seedlings in Ca-deficient soil (Nittler and Kenny, 1972). Therefore, color differences found here may be due to differential $\mathrm{Ca}$ absorption under saline conditions. Possibly in the presence of low $\mathrm{Ca}$ or high $\mathrm{Na}$, other cations, such as $\mathrm{Fe}$, were precipitated in the cytoplasm by organic acids, which were produced in response to salinity stress (Osmond, 1963).
Top growth and root growth correlated better with solution conductivity than with leaf elemental content (Table 2). This relationship suggests that the bulk of the growth reductions were due to osmotic effects and not a nutritional imbalance. This conclusion is similar to that formed by Hughes et al. (1975). that tissue nutrient content does not always relate directly to salinity tolerance. Differences in growth between 'Seville' and the other three cultivars may be related, in part, to nutritional differences. Tissue concentrations of $\mathrm{Ca}, \mathrm{Mg}$, and $\mathrm{K}$ were not as highly correlated with top growth of 'Seville' as with the other three cultivars. Chlorine and $\mathrm{Na}$ also appear to be involved in the cultivar differences. Chlorine content of leaves correlated very highly to

Table 5. Correlation coefficients of elemental content of leaves and color scores for four St. Augustinegrass cultivars grown in six levels of saline solution medium.

\begin{tabular}{lccccc}
\hline \hline Cultivar & $\mathrm{Ca}$ & $\mathrm{K}$ & $\mathrm{Mg}$ & $\mathrm{Na}$ & $\mathrm{Cl}$ \\
\hline Floralawn & 0.685 & 0.587 & 0.304 & -0.513 & -0.320 \\
& $* * *$ & $* * *$ & $\mathrm{NS}$ & $*$ & $\mathrm{NS}$ \\
Floratam & 0.559 & 0.567 & 0.318 & -0.379 & -0.220 \\
& $* * *$ & $* * *$ & $\mathrm{NS}$ & $*$ & $\mathrm{NS}$ \\
Floratine & 0.712 & 0.529 & 0.629 & -0.473 & -0.246 \\
& $* * *$ & $* *$ & $* * *$ & $\mathrm{NS}$ \\
Seville & 0.400 & 0.398 & 0.401 & -0.265 & -0.217 \\
& $*$ & $*$ & $*$ & $\mathrm{NS}$ & $\mathrm{NS}$ \\
\hline
\end{tabular}

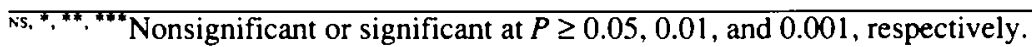


solution conductivities for all four cultivars, but $\mathrm{Cl}$ was not as highly correlated with top growth in 'Seville' as with top growth in the other three cultivars. The same pattern held true for $\mathrm{Na}$, although correlation coefficients are of a lower magnitude (Table 2 ). This, combined with the fact that no significant interaction was found for leaf $\mathrm{Cl}$ or $\mathrm{Na}$ content with $\mathrm{EC}$ (Table 1), suggests that 'Seville' is more efficient at synchronizing uptake and compartmentalizing these ions than at differentiating ion uptake and assimilation.

Growth reductions in St. Augustinegrass due to excess soluble salts in the root zone are a function of loss of turgor potential and ionic imbalances in the tissue (Marschner, 1986). The relative contributions of these two factors are difficult to ascertain, but this research suggests that osmotic stress is more important in overall growth reductions, while ionic differences in the tissue account for cultivar differences in St. Augustinegrass. 'Seville' is by far the most tolerant to salinity in the root zone among these fourcultivars.

\section{Literature Cited}

Ahmad, I., S.J. Wainwright, and G.R. Stewart. 1981. The solute and water relations of Agrostis stolonifera ecotypes differing in their salt tolerance. New Phytol. 87:615-629.

Beard, J.B. 1973. Turfgrass: Science and culture. Prentice Hall, Englewood Cliffs, N.J.

Bernstein, L. and H.E. Hayward. 1958. Physiology of salt tolerance. Annu. Rev. of Plant Physiol. 9:25-46.

Cope, Jr., J.T., R. Bradfield, and M. Peech. 1953. Effects of sodium fertilization on yield and cation content of alfalfa and cotton. Soil Sci. 76:65-74.

Cordukes, W.E. and E.V. Parups. 1971. Chloride uptake by various turfgrass species and cultivars. Can. J. Plant Sci. 51:485-490.

Devitt, D., L.H. Stolzy, and W.M. Jarrell. 1984. Responses of sorghum and wheat to different $\mathrm{K}^{+} / \mathrm{Na}^{+}$ratios at varying osmotic potentials. Agron. J. 76:681-685.

Dudeck, A.E., S. Singh, C.E. Giordano, T.A. Nell, and D.B. McConnell. 1983. Effects of sodium chloride on Cynodon turfgrasses. Agron. J. 75(6):927-930

Dudeck, A.E. and C.H. Peacock. 1985. Effects of salinity on Seashore Paspalum turfgrasses. Agron. J. 77(1):47-50.
Elgabaly, M.M. 1955. Specific effects of absorbed ions on plant growth: 1. Effect of different combinations of calcium, magnesium, and sodium on barley seedlings. Soil Sci. 80:235-238.

Francois, L.E. 1988. Salinity effects in three turf bermudagrasses. HortScience. 23:706-708

Greenway, H. and R. Munns. 1980. Mechanism of salt tolerance in nonhalophytes. Annu. Rev. Plant Physiol. 31:149-190.

Harivandi, M.A., J.D. Butler, and P.N. Soltanpour. 1982. Effects of sea water concentrations on germination and ion accumulation in alkaligrass ( Puccinellia spp.). Commun. Soil Sci. Plant Anal. 13(7):507-515.

Hewitt, E.J. 1963. The essential nutrient elements: Requirements and interactions in plants. vol. III, p. 137-360. In: F.C. Steward (ed.). Plant physiology, a treatise. Academic Press, New York.

Hughes, T.D., J.D. Butler, and G.D. Sanks. 1975. Salt tolerance and suitability of various grasses for saline roadsides. J. Environ. Quality 4(1):65-68

Lunt, O.R., V.B. Youngner, and J.J. Oertli. 1961. Salinity tolerance of five turfgrass varieties. Agron. J. 53:247-249.

Marschner, H. 1986. Mineral nutrition of higher plants. Academic Press, New York.

Mitchell, Jr., C.C. and R.D. Rhue. 1979. Procedures used by the University of Florida Soil Testing and Analytical Research Laboratories. Soil Sci. Res. Rpt. 79-1. Univ. of Fla., Inst. Food Agr. Sci., Gainesville. Nittler, L.W. and T.J. Kenny. 1972. Cultivar differences among calcium-deficient Kentucky bluegrass seedlings. Agron. J. 64:73-75.

Osmond, C.B. 1963. Oxalate and ionic equilibria in Australian salt bushes. Nature. 198:503-504.

Parker, G.G. 1975. The hydrogeology and problems of peninsular Florida's water resources. Proc. Fla. Turf Grass Mgt. Conf. 22:13-36.

Rathert, G. 1982. Influence of extreme K:Na ratios and high substrate salinity on plant metabolism of crops differing in salt tolerance. V. Ion-specific salinity effects on invertase in leaves of bushbean and sugarbeet plants. J. Plant Nutr. 5(2):97-109.

Shannon, M.C. 1978. Testing salt tolerance variability among tall wheatgrass lines. Agron. J. 70:719-722.

Svedrup, H.V., M.W. Johnson, and R.H. Fleming. 1959. The oceans, their physics, chemistry, and general biology. Prentice Hall, Englewood Cliffs, N.J.

Wu, L. 1981. The potential for evolution of salinity tolerance in Agrostis stolonifera L. and Agrostis tenuis Sibth. New Phytol. 89:471-486.

Youngner, V.B. and O.R. Lunt. 1967. Salinity effects on roots and tops of Bermudagrass. J. British Grassland Soc. 22:257-259. 